
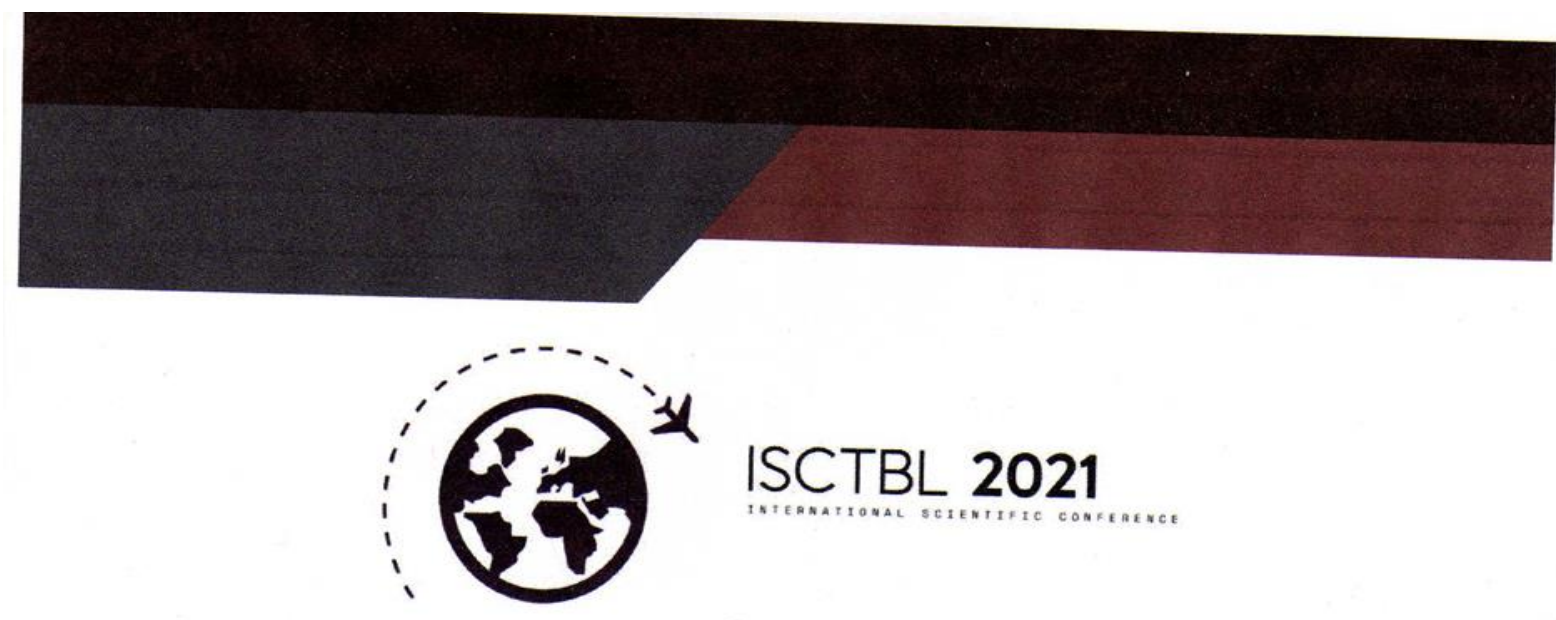

ISCTBL 2021

Универзитет „Гоце Делчев“ -

IIти тI

Goce Delchev University
Shtip

Факултет за туризам и бизнис

логистика

Faculty of Tourism

Business Logistics

and

Четврта Меѓународна Научна Конференција

Fourth International Scientific Conference

ПРЕДИЗВИЦИТЕ ВО ТУРИЗМОТ И БИЗНИС ЛОГИСТИКАТА ВО 21 ВЕК

CHALLENGES OF TOURISM AND BUSINESS LOGISTICS IN THE 21ST CENTURY

ЗБОРНИК НА ТРУДОВИ

CONFERENCE PROCEEDINGS 


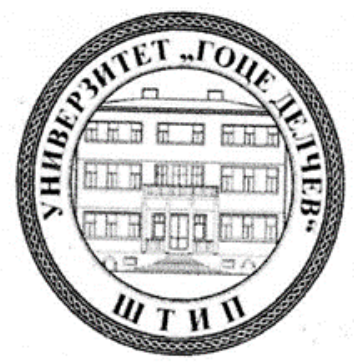

Универзитет „Гоце Делчев“ IIти II

Факултет за туризами бизнис логистика
Goce Delcev University Shtip

Faculty of Tourism Business Logistics

and

Четврта Меѓународна Научна Конференција Fourth International Scientific Conference

ПРЕДИЗВИЦИТЕ ВО ТУРИЗМОТ И БИЗНИС ЛОГИСТИКАТА ВО 21 ВЕК

CHALLENGES OF TOURISM AND BUSINESS LOGISTICS IN THE 21ST CENTURY

\section{ЗБОРНИК НА ТРУДОВИ CONFERENCE PROCEEDINGS}

19 ноември 2021 г. / November 19, 2021 


\section{Издавач:}

Факултет за туризам и бизнис логистика

Универзитет „Гоце Делчев““ - Штип

Крсте Мисирков, 10-А, 201, 2000, Штип, РС Македонија

Тел: +38932550350

www.ftbl.ugd.edu.mk

www.ugd.edu.mk

DOI https://www.doi.org/10.46763/9786082448244

За издавачот:

д-р Татјана Бошков, декан

Организатор на конференцијата:

Факултет за туризам и бизнис логистика

Тираж: 146

\section{Publisher:}

Faculty of Tourism and Business Logistics

Goce Delchev University of Shtip

"Krste Misirkov" no.10-A P.O. Box 201 Shtip 2000, North Macedonia

Tel: +38932550350

www.ftbl.ugd.edu.mk

www.ugd.edu.mk

\section{DOI https://www.doi.org/10.46763/9786082448244}

For the Publisher:

Tatjana Boshkov, Ph.D. - Dean

Conference Organizator:

Faculty of Tourism and Business Logistics

Print circulation: 146

CIP - Каталогизација во публикација

Национална и универзитетска библиотека Св. „Климент Охридски“, Скопје

$338.48(062)$

658.6/.8:164(062)

МЕЃУНАРОДНА научна конференција (4 ; Штип ; 2021)

Предизвиците во туризмот и бизнис логистиката во 21 век : зборник на трудови / Четврта меѓународна научна конференција, 19 ноември 2021, Штип = Challenges of tourism and business logistics in the 21 st

century :

conference proceedings / Fourth international scientific conference, November 19, 2021, Shtip. - Штип

Универзитет "Гоце Делчев", Факултет за туризам и бизнис логистика, 2021. - 390 стр. : илустр. ; $25 \mathrm{~cm}$

Трудови на мак. и англ. јазик. - Фусноти кон текстот. - Библиографија кон трудовите

ISBN 978-608-244-824-4

1. Напор. ств. насл.

a) Туризам -- Собири б) Синџир на снабдување -- Логистички системи -- Собири

COBISS.MK-ID 55376901 


\section{Организациски комитет:}

Проф. д-р. Татјана Бошков, Универзитет „Гоце Делчев“ - Штип, Факултет за Туризам и Бизнис логистика, Штип, Република Северна Македонија Доц. д-р. Наташа Митева, Универзитет „Гоце Делчев“ - Штип, Факултет за Туризам и Бизнис логистика, Штип, Република Северна Македонија

Доц. д-р Цветанка Ристова Магловска, Универзитет „Гоце Делчев“ - Штип, Факултет за Туризам и Бизнис логистика, Штип, Република Северна Македонија

Доц. д-р. Душко Јошески, Универзитет „Гоце Делчев“ - Штип, Факултет за Туризам и Бизнис логистика, Штип, Република Северна Македонија

\section{Меѓународен програмски комитет:}

Проф. д-р. Татјана Бошков, Универзитет „Гоце Делчев“ - Штип, Факултет за Туризам и Бизнис логистика, Штип, Република Северна Македонија

Доц. д-р. Наташа Митева, Универзитет „Гоце Делчев“ - Штип, Факултет за Туризам и Бизнис логистика, Штип, Република Северна Македонија

Доц. д-р. Цветанка Ристова Магловска, Универзитет „Гоце Делчев“ - Штип, Факултет за Туризам и Бизнис логистика, Штип, Република Северна Македонија

Доц. д-р. Душко Јошески, Универзитет „Гоце Делчев“ - Штип, Факултет за Туризам и Бизнис логистика, Штип, Република Северна Македонија

Проф. д-р. Мишко Џидров, Универзитет „Гоце Делчев“ - Штип, Машински факултет, Република Северна Македонија

Проф. д-р. Никола В. Димитров, Универзитет „Гоце Делчев“ - Штип, Факултет за Туризам и Бизнис логистика, Штип, Република Северна Македонија

Проф. д-р. Цане Котески, Универзитет „Гоце Делчев“ - Штип, Факултет за Туризам и Бизнис логистика, Штип, Република Северна Македонија

Проф. д-р. Александра Жежова, Универзитет „Гоце Делчев“ - Штип, Факултет за Туризам и Бизнис логистика, Штип, Република Северна Македонија

Доц. д-р. Оливер Филипоски, Универзитет „Гоце Делчев“ - Штип, Факултет за Туризам и Бизнис логистика, Штип, Република Северна Македонија

Проф. д-р. Зоран Темелков, Универзитет „Гоце Делчев“ - Штип, Факултет за Туризам и Бизнис логистика, Штип, Република Северна Македонија

Доц. д-р. Душица Попова, Универзитет „Гоце Делчев“ - Штип, Факултет за Туризам и Бизнис логистика, Штип, Република Северна Македонија

д-р Билјана Цоневска Гуњовска, Универзитет „Гоце Делчев“ - Штип, Факултет за Туризам и Бизнис логистика, Штип, Република Северна Македонија Проф. д-р. Тања Ангелкова Петкова, Универзитет „Гоце Делчев“ - Штип, Факултет за Туризам и Бизнис логистика, Штип, Република Северна Македонија Доц. д-р. Васко Шутаров, МИТ Универзитет, Факултет за безбедност, Р. С. Македонија Проф. д-р. Глигор Бишев, Универзитет „Св. Климент Охридски“ - Битола, Економски факултет Прилеп, Република Северна Македонија Проф. д-р. Мадалина Теодора Андреи, Универзитет Хиперион, Факултет за општествени, хуманистички науки и природни науки, Оддел за географија, Романија Проф. д-р. Соња Квирога, Универзитет Алкала, Оддел за економија, Шпанија Проф. д-р. Алиса Флеишер, Хебрејскиот универзитет Јерусалим, Роберт Х. Смит, Факултет за земјоделие, Храна и Животна средина, Оддел за економија на животна средина и управување, Израел

Проф. д-р. Ноам Шовал, Хебрејски универзитет Ерусалим, Факултет за општествени науки, Оддел за географија, Израел

Проф. д-р. Нурија Елиса Морере Молинеро, Универзитет Реј Хуан, Шпанија 
Проф. д-р. Никола Хурвулиадес, Американ Колеџ Солун, Грција

Проф. д-р. Донила Пипа, Универзитет Марин Барлети, Економски факултет, Албанија Проф. д-р. Мохамед Фуад, Ариш Универзитет, Факултет за уметност, Египет Проф. д-р. Френсис Вериза, Универзитет Толиара, Факултет за оппштествени науки, Мадагаскар

Проф. д-р. Октавиан Сербан, Букурешки Универзитет за Економија, Факултет за храна од земјоделие и економија на животната средина, Романија

Проф. д-р. Сабина Георгечи, Асоцијација за промоција на туризмот, Дробета ТурмуСеверин, Романија

Проф. д-р. Серафима Роскова, Молдовска академија за науки, Академија за економски науки на Молдавија, Република Молдавија

Проф. д-р. Стела Дерменџиева, Универзитет на Велико Трново Свети „Кирил и Методиј“, Оддел за Географија, Бугарија

Проф. д-р. Марта Боровска Стефанска, Универзитет во Лоџ, Факултет за Географски науки, Институт за градежна средина и Просторна, Полска

Проф. д-р. Јулиана Поп, Универзитет за економски студии, Факултет за бизнис и туризам, Романиа

Проф. д-р. Елена Тома, Универзитет Хиперион, Факултет за општествени, хуманистички науки и природни науки, Оддел за географија, Романија

Проф. д-р. Ирина Лазар, Универзитет Хиперион, Факултет за општествени, хуманистички науки и природни науки, Оддел за географија, Романија

Проф. д-р. Озгур Јерли, Дужче Универзитет, Факултет за Шумарство, Оддел за пејсажи, Турција

Доц. д-р. Жарко Радјеновиќ, Универзитет во Ниш, Центар за иновации, Србија Проф. д-р. Драго Цвијановиќ, Универзитет во Крагујевац, Факултет за Хотелски менаџмент и Туризам Врњачка Бања, Србија

Проф. д-р. Дарко Димитровски, Универзитет во Крагујевац, Факултет за Хотелски менаџмент и Туризам Врњачка Бања, Србија

Проф. д-р. Серџо Чипола, Универзитет во Палермо, Силиција, Италија

Доц. д-р. Марија Белиј, Универзитет во Белград, Факултет за географија, Србија Доц. д-р. Андреј Мичовиќ, Универзитет во Крагујевац, Факултет за Хотелски менаџмент и Туризам Врњачка Бања, Србија

Проф. д-р. Светлана Станкова, Универзитет во Шумен „Св. Константин Преславки“, Факултет за природни науки, Оддел за географија, регионален развој и туризмот, Шумен, Бугарија 


\section{Organizational committee:}

Prof. Tatjana Boshkov, Ph.D., Goce Delcev University of Stip, Faculty of Tourism and

Business logistics, Stip, North Macedonia

Assist. Prof. Natasa Miteva, Ph.D., Goce Delcev University of Stip, Faculty of Tourism and

Business logistics, Stip, North Macedonia

Assist. Prof. Cvetanka Ristova Maglovska, Ph.D., Goce Delcev University of Stip, Faculty of

Tourism and Business logistics, Stip, North Macedonia

Assist. Prof. Dusko Joseski, Ph.D., Goce Delcev University of Stip, Faculty of Tourism and

Business logistics, Stip, North Macedonia

International program committee:

Prof. Tatjana Boshkov, Ph.D., Goce Delcev University of Stip, Faculty of Tourism and

Business logistics, Stip, North Macedonia

Assist. Prof. Natasa Miteva, Ph.D., Goce Delcev University of Stip, Faculty of Tourism and

Business logistics, Stip, North Macedonia

Assist. Prof. Cvetanka Ristova Maglovska, Ph.D., Goce Delcev University of Stip, Faculty of Tourism and Business logistics, Stip, North Macedonia

Assist. Prof. Dusko Joseski, Ph.D., Goce Delcev University of Stip, Faculty of Tourism and

Business logistics, Stip, North Macedonia

Prof. Misko Djidrov, Ph.D., Goce Delcev University of Stip, Faculty of Mechanical

Engineering, Stip, North Macedonia

Prof. Nikola V. Dimitrov, Ph.D., Goce Delcev University of Stip, Faculty of Tourism and

Business logistics, Stip, North Macedonia

Prof. Cane Koteski, Ph.D., Goce Delcev University of Stip, Faculty of Tourism and Business logistics, Stip, North Macedonia

Prof. Aleksandra Zezova, Ph.D., Goce Delcev University of Stip, Faculty of Tourism and

Business logistics, Stip, North Macedonia

Assist. Prof. Oliver Filiposki, Ph.D., Goce Delcev University of Stip, Faculty of Tourism and

Business logistics, Stip, North Macedonia

Prof. Zoran Temelkov, Ph.D., Goce Delcev University of Stip, Faculty of Tourism and Business logistics, Stip, North Macedonia

Assist. Prof. Dusica Popova, Ph.D., Dusica Popova, Ph.D., Goce Delcev University of Stip,

Faculty of Tourism and Business logistics, Stip, North Macedonia

Biljana Conevska Gunjovska, Ph.D., Goce Delcev University of Stip, Faculty of Tourism and

Business logistics, Stip, North Macedonia

Prof. Tanja Angelkova Petkova, Ph.D., Goce Delcev University of Stip, Faculty of Tourism

and Business logistics, Stip, North Macedonia

Assist. Prof. Vasko Sutarov, Ph.D., MIT University, Faculty of Security Sciences, North

Macedonia

Prof. Gligor Bishev, Ph.D., St. Clement of Ohrid University of Bitola, Faculty of Economics,

Prilep, North Macedonia

Prof. Madalina Teodora Andrei, Ph.D., Hyperion University, Faculty of Social, Humanities and Natural Sciences, Department of Geography, Romania

Prof. Sonia Quiroga, Ph.D., University of Alcalá, Depatment of Economics, Spain

Prof. Aliza Fleischer, Ph.D., The Hebrew University of Jerusalem, The Robert H. Smith Faculty of Agriculture, Food and Environment, Department of Environmental Economics and

Management, Israel 
Prof. Noam Shoval, Ph.D., The Hebrew University of Jerusalem, Faculty of Social Sciences, The Department of Geography, Israel

Prof. Nuria Elisa Morère Molinero, Ph.D., Universidad Rey Juan Carlos, Catedrática Historia Antigua, Spain

Prof. Nikolas Hourvouliades, Ph.D., American College of Thessaloniki, Greece

Prof. Donila Pipa, Ph.D., Marin Barleti University, Faculty of Economy, Albania

Prof. Mohamed Fouad, Ph.D., Arish University, Faculty of Arts, Egypt

Prof. Francis Veriza, Ph.D., University of Toliara, Faculty of Lettets and Human Sciences,

Madagascar

Prof. Octavian Serban, Ph.D., Bucharest University of Economic Studies, Faculty of Agrifood and Environmental Economics, Romania

Prof. Sabina Gheorgheci, Ph.D., Mehedinți Tourism Promotion Association, Drobeta TurnuSeverin, Romania

Prof. Serafima Roșcovan, Ph.D., Moldova Academy of Science, Academy of Economic Studies of Moldova, Republic of Moldova

Prof. Stella Dermendzhieva, Ph.D., University of Veliko Turnovo St Cyril and St. Methodius, Department of Geography, Bulgaria

Prof. Marta Borowska-Stefanska, Ph.D., University of Lodz Faculty of Geographical Sciences, Institute of the Built Environment and Spatial Policy, Poland

Prof. Iuliana Pop, Ph.D., University of Economic Studies, Faculty of Business and Tourism,

Romania

Prof. Elena Toma, Ph.D., Hyperion University, Faculty of Social, Humanities and Natural

Sciences, Department of Geography, Romania

Prof. Irina Lazăr, Ph.D., Hyperion University, Faculty of Social, Humanities and Natural

Sciences, Department of Geography, Romania

Prof. Ozgur Yerli, Ph.D., Duzce University, Faculty of Forestry, Department of Landscape, Architecture, Turkey

Assist. Prof. Zarko Radjenovic, Ph.D., University of Nis, Innovation Center, Serbia

Prof. Drago Cvijanović, Ph.D., University of Kragujevac, Faculty of Hotel Management and Tourism in Vrnjacka Banja, Serbia

Prof. Darko Dimitrovski, Ph.D., University of Kragujevac, Faculty of Hotel Management and

Tourism in Vrnjacka Banja, Serbia

Prof. Sergio Cipolla, Ph.D., University of Palermo, Italia

Assist. Prof. Marija Belij, Ph.D., University of Belgrade, Faculty of Geography, Serbia

Assist. Prof. Andrej Mićović, Ph.D., University of Kragujevac, Faculty of Hotel Management and Tourism in Vrnjacka Banja, Serbia

Prof. Svetlana Stankova, University of Shumen "Konstantin Preslavski”, Faculty of natural science, Department of geography, regional development and tourism, Bulgaria 


\section{Содржина - Contents}

СЕСИЈА: БИЗНИС ЛОГИСТИКА И БИЗНИС АДМИНИСТРАЦИЈА ……................... 15

SESSION: BUSINESS LOGISTICS \& BUSINESS ADMINISTRATION ......................... 15

Tatjana Boshkov; Mishko Djidrov - CIRCURAL ECONOMY DEVELOPMENT

AND RESOURCE EFFICIENCY: EVIDENCE FOR MACEDONIA …........................... 17

Dushko Joseski; Tatjana Boshkov - MONETARY ECONOMICS: POST-KEYNESIAN

STOCK-FLOW CONSISTENT APPROACH (PK-SCF) VERSUS NEW-KEYNESIAN

DYNAMIC STOCHASTIC GENERAL EQUILIBRIUM (NK-DSGE)............................25

Елизабета Митрева; Трајанка Стојменова; Златко Трајковски - ПРИМЕНА НА

МЕТОДОЛОГИЈАТА НА ДИГИТАЛНИ ЛОГИЧКИ СИСТЕМИ ВО ТРАНСПОРТОТ

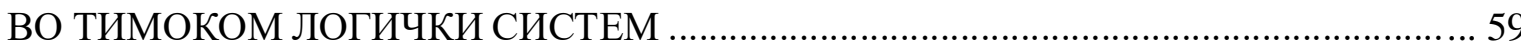

Емануела Есмерова; Драшко Атанасоски - МОДЕЛИ НА РАЗВОЈ НА ЧОВЕЧКИТЕ

РЕСУРСИ ВО ЕКОНОМИЈАТА НА ПРЕТПРИЈАТИЈА............................................... 72

Марија Магдинчева-Шопова; Анета Стојановска-Стефанова - ПОЛИТИКИ И

ПРАКТИКИ ЗА РАЗВОЈ НА СОЦИЈАЛНОТО ПРЕТПРИЕМНИШТВО ...................... 80

Анета Стојановска-Стефанова; Марија Магдинчева-Шопова; Христина Рунчева-Тасев

- СОЦИО-ЕКОНОМСКОТО ВЛИЈАНИЕ НА КОВИД-19: МАКЕДОНСКИОТ

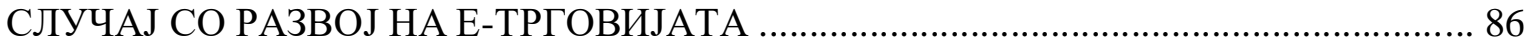

Žarko Rađenović - TRANSPORTATION MANAGEMENT SYSTEMS: LOGISTICS

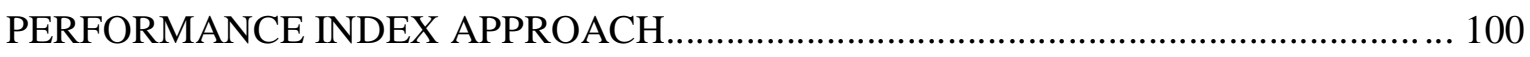

Ивица Јосифовиќ; Игор Камбовски - ВИЗНАТА ПОЛИТИКА НА ЕВРОПСКАТА

УНИЈА ВО ДОГОВОРОТ ОД ЛИСАБОН: ПРЕДИЗВИЦИ И ПЕРСПЕКТИВИ .........109

Svetla Panayotova; Ventsislava Nikolova-Minkova - IMPORTANCE OF INTELLECTUAL

PROPERTY FOR SMEs IN THE DIGITAL ECONOMY ........................................... 120

Ventsislava Nikolova-Minkova - ECONOMIC PERSPECTIVES ON INTELLECTUAL

PROPERTY MANAGEMENT............................................................................ 128

Mimoza Serafimova; Bobana Stefanoska - SOCIO-ECONOMIC IMPACT OF COVID-19

CRISIS ON HUMAN RESOURCES AND COMPANIES............................................... 135

Александра Жежова - ОДНЕСУВАЮЕТО НА ЛИЧНОСТА И ПОЗИЦИЈАТА НА

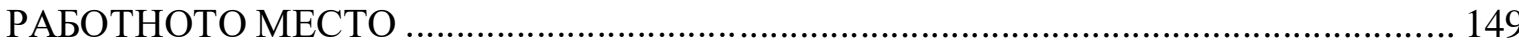

СЕСИЈА: ТУРИЗАМ, УГОСТИТЕЛСТВО И ГАСТРОНОМИЈА.......................... 159

SESSION: TOURISM, HOSPITALITY \& GASTRONOMY ......................................... 159

Dushica Popova; Natasha Miteva - SERVICE QUALITY MODELS IN HOSPITALITY

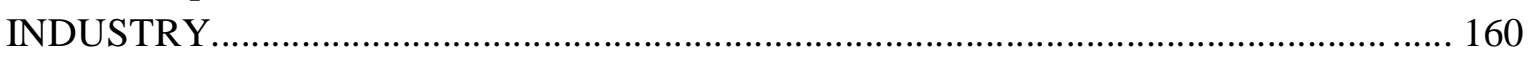

Cvetanka Ristova Maglovska; Ivan Durgutov - REBUILDING TOURISM AND TRAVEL

FOR THE FUTURE: POLICY RESPONSES TO THE CORONAVIRUS (COVID-19).... 167 
Љупчо Јаневски; Климент Наумов - ЕКОТУРИЗМОТ КАКО СПЕЦИФИЧНА ТУРИСТИЧКА ФОРМА ВО НАЦИОНАЛНИТЕ ПАРКОВИ НА РС МАКЕДОНИЈА

Tatjana Dimitrova; Slavi Dimitrov - TOURISM MANAGEMENT THROUGH PLANNING DOCUMENTS AT REGIONAL AND LOCAL LEVEL

НикоЛа В. ДимИтров - РЕГИОНАЛЕН ПРЕГЛЕД НА ПЛАНИНСКИОТ ТУРИЗАМ ВО РС МАКЕДОНИЈА.

Душица Матета Гигова; Елизабета Митева - ГЛОБАЛИЗАЦИЈАТА И ТУРИЗМОТ ВО РЕПУБЛИКА СЕВЕРНА МАКЕДОНИЈА

Dora Kabakchieva - ADDITIONAL VALUE END EFFECT OF DIGITALIZATION IN TOURISM

Илија ЗакосКИ - УЛОГА НА ИНТЕРНЕТОТ ПРИ ИЗБОР НА ТУРИСТИЧКА ДЕСТИНАЦИЈА И ОРГАНИЗАЦИЈА НА ТУРИСТИЧКОПАТУВАњЕ

Dragan Tezanovik; Sanja Filipovic; Maja Banjak - COFFEE AS A SIGNIFICANCE

SEGMENT OF THE CATERING OFFER - CASE STUDY OF THE CITY NIŠ

Biljana Petrevska; Dajana Bjelajac; Bojan Djercan - DARK SKY TOURISM: PROSPECTS

AND CHALLENGES FOR NORTH MACEDONIA

Перпарим К'ахили - КЛИМАТСКИ И ХИДРОГРАФСКИ КАРАКТЕРИСТИКИ ВО

РАЗВОЈОТ НА ТУРИЗМОТ ВО РЕГИОНОТ ЈИЛАН

Дарко Мајхошев; Цане Котески - ЛИСТИ НА УНЕСКО ЗА ЗАШТИТА НА

СВЕТСКОТО НАСЛЕДСТВО СО ПОСЕБЕН ОСВРТ НА ЛИСТАТА НА СВЕТСКО

НАСЛЕДСТВОВО ОПАСНОСТ

Monika Angeloska- Dichovska; Katerina Bojkovska; Elizabeta Tosheva - INNOVATION

STRATEGIES FOR YOUTH TOURISM AS A CONTIBUTION TO THE ECONOMIC

DEVELOPMENT OF THE WESTERN BALKAN COUNTRIES.

Naser Bresa - VERMICA -TOURIST OASIS, CULTIVATOR AND SERVER OF TROUT

Арбен Халили; Мислим Зендели - АПИТУРИЗАМ КАКО НОВА ДИМЕНЗИЈА ЗА

ПАТУВАњЕ НИЗ ШАР ПЛАНИНА.

Билјана Николовска - ПРЕДИЗВИЦИ И ИНОВАЦИИ НА МАКЕДОНСКИТЕ 
Зоран НикоЛОВсКИ - ОРГАНИЗАЦИЈА И КЕТЕРИНГ НА ДЕЛОВНИ НАСТАНИ НИЗ ПРИЗМА НА МАКЕДОНСКИТЕ КЕТЕРИНГ КОМПАНИИ

Vanya Vasileva; Iliana Dimitrova - DEVELOPMENT OF GOLF TOURISM ON THE

NORTHERN BULGARIAN BLACK SEA COAST.

Васко Шутаров - ГАСТРОДИПЛОМАТИЈА ВО ВРЕМЕ НА ПАНДЕМИЈА

Velibor Tasevski - IMPACT OF THE COVID 19 PANDEMIC ON NUMBER OF

TOURISTS IN REPUBLIC OF N. MACEDONIA

Цане Котески; Александар Магдески - СОВРЕМЕНИ ФОРМИ НА МЕЃУНАРОДЕН

ТУРИЗАМ СО ПОСЕБЕН ОСВРТ НА ГРАДСКИОТ И ЕВЕНТ ТУРИЗМОТ.

Karlo Mac; Cvetan Kovac - THE IMPACT OF CRISIS ON THE SEASONALITY OF

CROATIAN TOURISM AFTER 2000

ЗлаТко Јаковлев - МЕНАџМЕНТ НА АНИМАЦИЈАТА ВО ТУРИСТИЧКО -

УГОСТИТЕЛСКИТЕ ПРЕТПРИЈАТИЈА

Тања Ангелкова Петкова; Цветанка Ристова Магловска - ЗНАЧЕњЕТО НА ТУРИСТИЧКИТЕ АГЕНЦИИ ЗА РАЗВОЈ НА МАКЕДОНИЈА КАКО АТРАКТИВНА ТУРИСТИЧКА ДЕСТИНАЦИЈА 
Четврта Меѓународна Научна Конференција

ПРЕДИЗВИЦИТЕ ВО ТУРИЗМОТ И БИЗНИС ЛОГИСТИКАТА ВО 21 ВЕК »ISCTBL

$2021 \ll$

Fourth International Scientific Conference

CHALLENGES OF TOURISM AND BUSINESS LOGISTICS IN THE 21ST CENTURY

»ISCTBL 2021《264

UDK 338.483.12:930.85]:061.1UNESKO(100)

\title{
ЛИСТИ НА УНЕСКО ЗА ЗАШТИТА НА СВЕТСКОТО НАСЛЕДСТВО СО ПОСЕБЕН ОСВРТ НА ЛИСТАТА НА СВЕТСКО НАСЛЕДСТВО ВО ОПАСНОСТ
}

\author{
Дарко Мајхошев ${ }^{1}$; Цане Котески ${ }^{2}$ \\ Универзитет " Гоце Делчев"-Штип, darko-majhosev@hotmail.com \\ Универзитет " Гоце Делчев"-Штип, cane.koteski@ugd.edu.mk
}

\begin{abstract}
Апстракт
УНЕСКО како специјализирана организација на ООН има мисија за заштита, унапредување и промовирање на образованието, науката и културата на глобално ниво во функција на унапредување и почитување на човековите права. УНЕСКО во рамките на своите активности поврзани со заштитата на светското природно и културно наследство води посебни Листи за поедини области. Најпознати листи што ги води оваа организација се: Листа на места на светско културно и природно наследство (World Heritage List); Листа на светско културно и природно наследство во опасност (List of World Heritage in Danger); Листа на номинации за светско наследство (World Heritage List Nominations); Листа на глобални геопаркови (List of UNESCO Global Geoparks), Листа на креативни градови (List of the Creative Cities), Листа на нематеријално културно наследство (Lists of Intagible Cultural Heritage); Атлас (Мапа) на УНЕСКО на јазици во опасност (UNESCO Atlas of the Worlds Languages in Danger), Листа на резерви на биосферата (Biosphere reserves), Регистар на светски сеќавања (Memory of the world Register). Во овој труд авторите ќе направат истражување на Листите на УНЕСКО за заштита на светското природно и културно наследство, со посебен осврт на значењето на Листата на светско наследство во опасност. Во трудот ќ ја опишеме и процедурата на ставање на светското наследство на Листата во опасност, а ќе се осврнеме и на одлуката на 44 сесија на Комитетот за заштита на светското наследство во контекст на Охридскиот регион.
\end{abstract}

Клучни зборови: УНЕСКО, светско наследство, листи, заштита, туризам

\section{Видови на Листи на УНЕСКО за заштитата на светското природно и културното наследство}

УНЕСКО во рамките на своите активности поврзани со заштитата на светското природно и културно наследство води посебни Листи за поедини области. Најпознати листи што ги води оваа организација се:

1) Листа на места на светско културно и природно наследство (World Heritage List);

2) Листа на светско културно и природно наследство во опасност (List of World Heritage in Danger); 
3) Листа на номинации за светско наследство (World Heritage List Nominations);

4) Листа на глобални геопаркови (List of UNESCO Global Geoparks);

5) Листа на креативни градови (List of the Creative Cities);

6) Листа на нематеријално културно наследство (Lists of Intagible Cultural Heritage);

7) Атлас (Мапа) на УНЕСКО на јазици во опасност (UNESCO Atlas of the Worlds Languages in Danger);

8) Листа на резерви на биосферата (Biosphere reserves); $u$

9) Регистар на светски сеќавања (Memory of the world Register).

Горенаведени Листи (списоци, регистри и мапи) се важни и за заштита на светското природно и културно наследство, но имаат одредено влијание и врз одржливиот развој на туризмот на глобално ниво. Република Македонија, како членка на УНЕСКО од 1993 година со своите природни убавини и културно-историското наследство се најде на некои од наведените листи. Охридскиот Регион уште од 1979 и 1980 година се најде на Листата на места на светско природно и културно наследство, а во 2017 година, од страна на Комитетот за светско наследство, беше номиниран на Листата на светско наследство во опасност поради неконтролирана експанзија на туризмот, непланскиот урбанистички развој и уништување на животната средина во Охридскиот Регион. Обврската за евиденција произлегува од одредбите на Конвениијата за заштита на светското културно и природно наследство (1972) и Конвениијата за заштита на нематеријалното културно наследство (2003) на УHECKO.

\section{Карактеристики и специфики на листите на УНЕСКО}

На Листата на УНЕСКО за местата на светско културно и природно наследство се наоѓаaт 1.129 места, од кои 877 културни, 213 природни, 39 комбинирани кои се наоѓаат на териториите во 167 држави. ${ }^{1}$ Комитетот за светско наследство на УНЕСКО, 52 природни локалитети ги стави на Листата на светско културно и природно наследство во опасност лоцирани во 32 држави во светот, од кои најмногу се од Африка и Блискиот исток. Куриозитет претставува Одлуката на Комитетот донесена во 2017 година, со која историскиот центар на Виена е ставен на Листата на светско културно и природно наследство во опасност поради девастација на културно-историското наследство лоцирано во центарот на градот.

Листа на светско наследство во опасност (List of World Heritage in Danger). УНЕСКО подготвува и Листа на светско наследство во опасност кое е загрозено поради вооружени конфликти и војна, земјотрес и други природни катастрофи, загадување, неконтролирана урбанизација. ${ }^{2}$ Во 2019 година на Листата на светско богатство во опасност има вкупно 52 имоти на УНЕСКО. ${ }^{3}$

Листа на номинации за светско наследство (World Heritage List Nominations). Трет вид на водење на листа на УНЕСКО е Листа на номинации за светско наследство. Првиот чекор што земјата членка мора да го направи е „список“ на нејзините важни локации на природно и културно наследство лоцирани во рамките на нејзините граници. Овој „список“ е познат како „Предвремен список“ и обезбедува предвидување на имотите што државата-членка може да одлучи да ги поднесе за ставање на националната листа за номинација во следните пет до десет години и кои можат да се ажурираат во секое време. Тоа е важен чекор, бидејќи

\footnotetext{
1 http://whc.unesco.org/en/list, пристапено на ден 26.07.2021 година;

2 http://whc.unesco.org/en/158/, пристапено на 26.07.2021;

${ }^{3}$ https://whc.unesco.org/en/danger/, пристапено на ден 20.07.2019;
} 
Комитетот за светско наследство не може да смета на номинација за запишување на списокот на светско наследство, освен ако имотот веќе не е вклучен во заложната листа на државата членка. ${ }^{4}$

Листа на глобални геопаркови (List of UNESCO Global Geoparks). УНЕСКО води Листа на глобални геопаркови и бројот на веб-локации во Глобалната мрежа на геопаркови на УНЕСКО изнесува 169 во 44 земја. ${ }^{5}$ Во април 2019 година, Извршниот одбор на УНЕСКО го одобри запишувањето на осум нови локации кои ја демонстрираат различноста на геологијата на планетата како нови Геопаркови. Во 2021 година до УНЕСКО се поднесени се 16 нови апликации за процес на евалуација за запишување во Листата на глобални геопаркови. ${ }^{6}$

Листа на нематеријално културно наследство (Lists of Intangible Cultural Heritage). Oваа Листа е воведена во 2008 година, врз основа на одредбите на Конвенцијата за зачувување на нематеријалното културно наследство од 2003 година. Комитетот за зачувување на нематеријалното културно наследство се состанува на годишно ниво за да ги процени номинациите предложени од државите потписнички на Конвенцијата и одлучува дали да ги вметне или не на Листата на нематеријално културно наследство и на Регистарот на добро зачувани практики. Со кликнување на впишаните филтер елементи на веб-страницата, може да се прелистат и откријат сите номинации, но и добро зачувани практики во државите. ${ }^{7}$

Атлас на УНЕСКО на јазици во опасност (UNESCO Atlas of the Worlds Languages in Danger). УНЕСКО има подготвено две изданија на Атласот на јазици во опасност онлајн и во печатена форма. Атласот нуди информации за загрозените јазици во светот, но претставува и алатка со која секој може да предложи загрозен јазик кој ке биде ставен на Атласот.

Листа на креативни градови (List of the Creative Cities). Мрежата за креативни градови е формирана во 2004. Мрежата опфаќа седум креативни области: занаети и народни уметности, медиуми уметности, филм, дизајн, гастрономија, литература и музика. На 30 октомври 2019 година, Генералниот директор на УНЕСКО, Одри Азулеј, назначи нови 66 градови како креативни градови на УНЕСКО и во моментот оваа мрежа ја сочинуваат 246 града. Како лаборатории за идеи и иновативни практики, креативните градови на УНЕСКО донесуваат значаен придонес за постигнување на целите за одржлив развој преку иновативно размислување и дејствување. За да станат членки на Мрежата на креативни градови на УНЕСКО, градовите кандидати мора да поднесат апликација која јасно ја покажува нивната подготвеност, посветеност и капацитет да придонесат за целите на Мрежата.На оваа Листа од нашата држава се наоѓа Битола како креативен град на филмот.

Листа на резерви на биосферата (Biosphere reserves). Резервите на биосферата се области што содржат копнен, поморски и крајбрежен екосистем. Резервите на биосферата се номинирани од националните влади и остануваат под суверена надлежност на државите каде што се наоѓаат. Нивниот статус е меѓународно признат. Постојат 714 биосфера резерви во 129 земји, вклучително и 21 прекугранични места. Тие се распоредени: 85 места во 31 земји во Африка, 33 места во 12 земји во арапските држави, 157 места во 24 земји во Азија и Пацификот, 302 места во 38 земји во Европа и Северна Америка и 130 места во 21 земја во Латинска Америка и Карибите. ${ }^{8}$

Регистар на светски сеќавања (Memory of the world Register). УНЕСКО ја воспостави програмата Меморија на светот во 1992. Овој регистар посочува документарно наследство

\footnotetext{
${ }^{4}$ http://whc.unesco.org/en/nominations/, пристапено на 08.07.2019;

5 http://www.unesco.org/new/en/natural-sciences/environment/earth-sciences/unesco-global-geoparks/, отворена на ден 26.07.2021;

${ }^{6} \mathrm{http}: / /$ www.unesco.org/new/en/natural-sciences/environment/earth-sciences/unesco-globalgeoparks/applicationprocess/, отворена на ден 27.07.2021;

${ }^{7}$ https://ich.unesco.org/en/lists, отворена на ден 15.08.2021;

${ }^{8}$ https://en.unesco.org/biosphere/wnbr, отворена на ден 27.07.2021;
} 
кое има светско значење и голема универзална вредност. Номинација за Регистарот може да поднесе секое лице или организација, вклучително и влади и невладини организации. Приоритет ќе имаат номинациите поднесени од или преку релевантната регионална или национална меморија на Светскиот комитет, каде што постои, или ако тоа не успее, преку соодветната Национална комисија на УНЕСКО. Се номинираат во Регистарот само оние документи кои имаат светско и универзално значење. Заклучно со август 2021 година, во Регистарот на светски сеќавања се запишани вкупно 429 предмети. ${ }^{9}$ Потекнува од зголемената свест за страшната состојба на зачувување и пристап до документарното наследство во различни делови на светот. Војните и општествените пресврти, како и сериозен недостаток на ресурси, ги влошија проблемите што постојат со векови. Значајни збирки низ целиот свет претрпеа различни судбини.

\section{Природно и културно наследство од Република С. Македонија на Листите на УНЕСКО и нивно влијание врз развојот на туризмот}

Република Северна Македонија има големо природно и културно наследство. На девет Листи што ги води УНЕСКО на четири од нив се наоѓa природно и културно наследство кое потекнува, се наоѓa или практикува на територијата на РС Македонија. Тие се: Листата на местата на светско културно и природно наследство, Листа на нематеријално културно наследство, Листа на креативни градови и Листа на резерви на биосферата.

На Листата на места на светско културно и природно наследство на УНЕСКО е запишан Градот Охрид и неговата околина со Одлука бр. CC-79/CONF.003/13 на Комитетот за светско наследство на Третата сесија одржана од 22.10. - 26.10.1979 година во Луксор, Египет. Во 1979 година, Охридскиот Регион прво е впишан на Листата на светско наследство по основ на својство на природно наследство, според критериум (iii) за суперлативните природни феномени што денес е критериум (vii). Во 1980 година, имотот на светското наследство на Охридскиот Регион е проширен и на културните критериуми (i), (iii) i (iv) и станува едно од првите мешани својства на светско наследство. Поради неконтролираното уништување и експлоатација на животната средина и природните убавини на сметка на развивање на туризмот, загадување на водата на Езерото со отпадни води и цврст отпад, големиот број на диви градби во близина на брегот на Охридското Езеро (1 076 нелегални градби), од кои 80 се од цврст материјал: куќи, апартмани и објекти за сместување (хотели)... Непостоењето на систем (план) за интегрално управување со Охридскиот Регион, брзи урбани и туристички развојни проекти, несоодветни инфраструктурни и сообраќајни проекти и сл., Охридскиот Регион се доведе во ситуација да биде предложен, од страна на Комитетот за заштита на светското наследство на УНЕСКО, за да биде ставен на Листа на светско наследство во опасност (List of World Heritage in Danger).

На 43-та сесија на Комитетот за заштита на светското наследство што се одржа во Баку, Азербејџан (30.6.-10.7.2019) се донесе одлука за времено одложување на Одлуката за ставање на Листата на светско наследство во опасност до февруари 2020 година. До овој период Македонската влада и локалните самоуправи на Охрид, Струга и Дебарца треба да преземат соодветни мерки и активности за отстранување на пречките кои се посочени во Извештајот на Комитетот за заштита на светското наследство. Исто така, на 43-та сесија на Комитетот, донесена е Одлука делот на Охридското Езеро што припаѓa на Албанија да биде под заштита на УНЕСКО, со што Охридскиот Регион и Охридското Езеро во целост потпаднаа под заштита на оваа меѓународна организација. ${ }^{10}$ Бидејќи до февруари 2021 година, надлежните

\footnotetext{
${ }^{9} \mathrm{http}: / /$ www.unesco.org/new/en/communication-and-information/memory-of-the-world/register/full-list-of-registeredheritage/registered-heritage-page-8/, отворена на ден 10.08.2021 година

${ }^{10}$ Во февруари 2018 година Република Албанија поднесе Апликација за номинирање на делот на Охридското Езеро што се наоѓa на територијата на Албанија на Листата на светско наследство на УНЕСКО. На 43 -та Сесија на Комитетот за заштита на светското наследство на УНЕСКО, во Баку, Азербејџан, донесена е Одлука и делот на Охридското Езеро на територијата на Албанија да биде под заштита на УНЕСКО.
} 
институции во државата не ги презедоа сите потребни мерки и активности, Реактивната мисија на УНЕСКО предложи Охридскиот регион повторно да биде ставен на Листата на светско наследство во опасност.

На 44 сесија на Комитетот за заштита на светското наследство што се одржа од 16.07.31.07.2021 година во Фуџу, Кина, на предлог на Националната комисија на УНЕСКО на Босна и Херцеговина, а поддржан од делегациите на Русија, Кина, Унгарија, Саудиска Арабија и Гватемала, Комитетот донесе Одлука, Охридскиот регион да не се стави на Листата на светско наследство во опасност, но доби рок до 01.02.2023 година да ги исполни препораките на УНЕСКО дадени во Извештајот. Со оваа одлука, Република Северна Македонија и Албанија се обврзаа да донесат заеднички стратешки план за рехабилитација на Регионот и дополнително да го подигнат нивото на билатералната заштита и управување со светското наследство.

Исто така, на 44 сесија на Комитетот на УНЕСКО за заштита на светското наследство во проширен состав, на ден 28.07.2021 година, донесе Одлука за проширување на постојното транснационално природно наоѓалиште Антички и исконски букови шуми на Карпатите и другите региони на Европа - продолжување (31/1/2019), да се стави и локалитетот (подрачјето) Длабока Река на планината Кораб, кој е дел од НП "Маврово". Ова подрачје се карактеризира со недопрена букова шума од човекот во последните 100 години. По Охридскиот Регион кој е прогласен за мешано наследство, природно и културно, буковата шума која се наоѓа по течението на Длабока Река е второ природно добро од земјава што се најде на листата на УНЕСКО. Номинацијата ја иницираше Министерството за животна средина и просторно планирање и Јавната установа Национален парк "Маврово", а е изработена со поддршка на Инститот за екологија од Клагенфурт, Австрија и национални експерти.

Со прогласувањето стана дел од досието "Древните и исконски букови шуми на Карпатите и други региони во Европа “, впишано на листата во 2007 година. Територијата на доброто е проширена во 2011 и во 2017 година, а од 28.07.2021 година уште десет земји се вкучени во споменикот на природата: Босна и Херцеговина, Чешка, Франција, Италија, Црна Гора, Северна Македонија, Полска, Србија, Словачка и Швајцарија. Проширувањето на транснационалното светско наследство „Древните и исконски букови шуми на Карпатите и други региони во Европа“" на десет европски земји ја зголемува исклучителната вредност и интегритетот на ова природно добро, кое сега содржи 94 компоненти во 18 земји. Проширената територија на ова добро претставува исклучителен пример на релативно ненарушен комплекс и го претставува широкиот спектар на севкупните еколошки процеси на чисти и мешани стојалишта на европската бука низ разни еколошки состојби. ${ }^{11}$

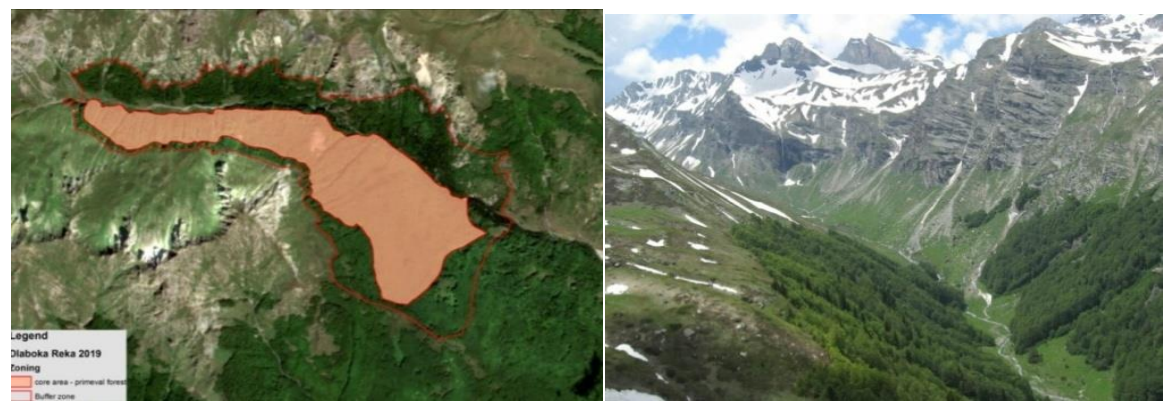

Сл. 1. Длабока Река на планината Кораб: Дел од транснационалното природно наоѓалиште Антички и исконски букови шуми во Европа

\footnotetext{
${ }^{11}$ Соопштение на УНЕСКО на ден 28.07.2021 година
} 
4) Листа на нематеријално културно наследство (Lists of Intangible Cultural Heritage) На оваа Листа се најдоа пет нематеријални културни наследства и практики кои потекнуваат и се практикуваат на територијата на Република С. Македонија. Тие се: 1) Празник на Светите четириесет маченици во Штип_запишано во 2013 година (Feast of the Holy Forty Martyrs in Shtip), Inscriebed in 2013 (8.COM); 2) Копачката, фолклорна игра од с. Драмче, Пијанец (Kopachkata, a social dance from the village of Dramche, Pijanec) -North Macedonia), Inscribed in 2014 (9.СОМ); 3) Гласоечко - машко двогласно пеење, Долни Полог (Glasoechko, male twopart singing in Dolni Polog (Macedonia), Inscriebed in 2015 (10.COM); 4) Културни практики поврзани со 1 март (Cultural practices associated to the 1st of March (BulgariaNorth Macedonia - Republic of Moldova-Romania), Inscribed in 2017 и 5) Пролетна прослава, Едерлези (Spring celebration, Hidrellez (North Macedonia and Turkey), Inscribed in 2017 $(12 . C O M) .{ }^{12}$

Листа на креативни градови (List of Creative Cities). На оваа Листа од нашата држава се наоѓa градот Битола како креативен град на филмот. Мрежата за креативни градови е формирана во 2004, а 180 града во моментот ја сочинуваат оваа мрежа. Филмското наследство на градот потекнува од почетокот на XX век, а филмската индустрија сега претставува столб на креативната економија на градот. Историјата на Битола со филмот датира од браќата Манаки кои како пионери во филмот и фотографија ја доведоа во Битола - порано именуван Манастир - филмска камера „Вioscope 300“. Браќата Манаки ги направиле првите фотографии со снимки на Балканот од Отоманскиот период. Во нивна чест, секоја година од 1979 година се одржува на далеку познатиот Меѓународен филмски фестивал „Браќа Манаки“. Од неодамна Општината Битола воведе две главни програми посветени на поддршка на креирањето филмови: Отвореното студио „Film City“ и „Filmland Bitola“. Обете програми имаат за цел да ја промовираат креативната индустрија и да го направат градот меѓународно познат центар за филм. ${ }^{13}$

Листа на резерви на биосферата (Biosphere reserves). На оваа Листа од нашата држава од 2014 година се наоѓ Регионот Охрид-Преспа како заедничко резерва на биосферата со Албанија ((The Ohrid-Prespa Transboundary Biosphere Reserve). Областа е распространета на основна површина: 14 339,25 хектари (13 457,81 ха копнена; 881,44 ха водна). Областа е комбинација на вода (езера, потоци), шума и планински релјефи додека рамните области граничат со надворешните граници на териториите што се протегаат низ двете земји. Заедно, системот на Охридското и Преспанското Езеро е еден од најголемите во Европа од ваков вид. И двете езера се со посебна вредност на национално и меѓународно ниво заради нивната геолошка и биолошка посебност. Охридското Езеро е познато по над двесте ендемични видови во групи како што се дијатоми, олигохети, пијавици, пориферанци, трикладиди, мекотели, остратоди и риби. Исто така, постои уникатна и ендемична шумска заедница составена од шуми како што се широките листопадни шуми.

Листа на глобални геопаркови (List of UNESCO Global Geoparks). На оваа Листа од нашата држава засега не се наоѓ ниту еден геопарк. Од 2019 година започна да се подготвува студија и досие за геопаркот Кратово-Злетово кој Република С. Македонија планира да го номинира на Тентативната (пробната) листа на УНЕСКО (Милевски, ) за прием во глобалната мрежа на геопаркови.

До 2019 година на Тентативната листа (Tentative Lists) од нашата држава се ставени четири места и тоа: Антички и исконски букови шуми на Карпатите и другите региони на Европапродолжување (31/1/2019), Архео-астрономскиот локалитет „Кокино“ (30/1/2009), Пештера „Слатински Извор“ (24/6/2004), „Маркови Кули“ (24/6/2004), а на крајот од 2020 година номинирана е и црквата „Св. Горѓи“ во Курбиново.

\footnotetext{
${ }^{12}$ National Commissions for UNESCO, Annual Report, 2017, p. 132;

${ }^{13} \mathrm{https}$ ://en.unesco.org/creative-cities/bitola, otvorena na den 15.09.2019;
} 


\section{Листа на УНЕСКО на светско наследство во опасност}

До 2021 година на Листите на УНЕСКО за светско наследство се запишани вкупно 1154 локалитети кои се прогласени за светско наследство од кои 52 се наоѓаат на списокот во опасност. Списокот на светско наследство во опасност има за цел да ја информира меѓународната заедница за состојбите што ги загрозуваат својствата за кои имотот е запишан на листата на светско наследство и да поттикне корективни активности од државите каде е лоцирано светското наследство. Најголеми проблеми за локалитетите на светското наследство се вооружениот конфликт и војна, земјотреси и други природни катастрофи, загадување, ловокрадство, неконтролирана урбанизација и неконтролиран туристички развој. Опасностите се „констатираат“, преку утврдување на непобитни докази на постоење на непосредни закани или „потенцијални“, кога имотот се соочува со закани што можат да имаат негативни ефекти врз вредностите на неговото светско наследство.

Според Конвенцијата за светско наследство од 1972 година, имотот на светското наследство - како што е дефинирано во членовите 1 и 2 од Конвенцијата - може да биде запишан на Листата на светско наследство во опасност кога Комисијата ќе утврди дека состојбата на имотот се соочува специфична и докажана непосредна опасност, имотот се сочува со закани вооружен конфликт, климатски или геолошки закани на животната средина, намалување на популацијата, криволовство одговара на најмалку еден од критериумите во двата случаи опишани (ставови 179-180 од Оперативните упатства).

\section{Случаи на локации запишани на Листата на светско наследство во опасност}

Иранскиот град Бам: Поради катастрофалниот земјотресот во декември 2003 година во иранскиот град Бам, античката цитадела и околниот културен пејзаж на иранскиот град Бам, беше запишан на Листата на светско наследство во опасност во 2004.

Долина Бамијан во Авганистан: Овој културен пејзаж беше запишан на листата на светско наследство во опасност во 2003 година поради воени дејствија и експлозии на динамит. Делови од локацијата се недостапни поради поставени противпешадиски мини на самата локација. УНЕСКО, на барање на авганистанската влада, ги координира сите меѓународни напори за заштита и подобрување на авганистанското културно наследство, особено во Бамијан.

Историски град Забид во Јемен: Археолошкото и историското наследство на Забид сериозно се влоши во последниве години, кога $40 \%$ од неговите оригинални куќки беа заменети со бетонски згради. Во 2000 година, на барање на Владата на Јемен, Историскиот град Забид беше запишан на Листата на светско наследство во опасност. УНЕСКО им помага на локалните власти да развијат урбанистички план за заштита и да усвојат стратешки пристап за зачувување на ова светско наследство.

Националните паркови Гарамба, Кахузи-Биега, Салонга, Вирунга и резерватот за диви животни Окапи во Демократска Република Конго: Од 1994 година, сите пет локации на Светското наследство на ДР Конго беа запишани на листата на светско наследство во опасност поради војната и граѓанските конфликти во регионот на Големите езера. Во 1999 година, УНЕСКО започна меѓународна кампања за заштита, заедно со голем број меѓународни невладини организации за заштита, за заштита на живеалиштата на загрозени видови на животни, како што се планинската горила, северниот бел носорог и окапи.

\section{Регионална разместеност на светско наследство во опасност}

Според Листата на УНЕСКО на светски наследства во опасност утврдено е дека 52 места (локалитети) се наоѓаат во опасност во 32 држави во светот. Според регионалната разместеност на светските наследства во опасност фактичката состојба е следната: 21 во 
Арапските држави, 15 во Африка, 6 во Азија и Пацифик, 6 во Латинска Америка и Карибите и 4 во Европа и Северна Америка. Најголем дел од светските наследства во опасност се наоѓаaт во регионите каде има воени судири и природни катастрофи. Подолу ја даваме Мапата на географската разместеност на светското наследство во опасност.

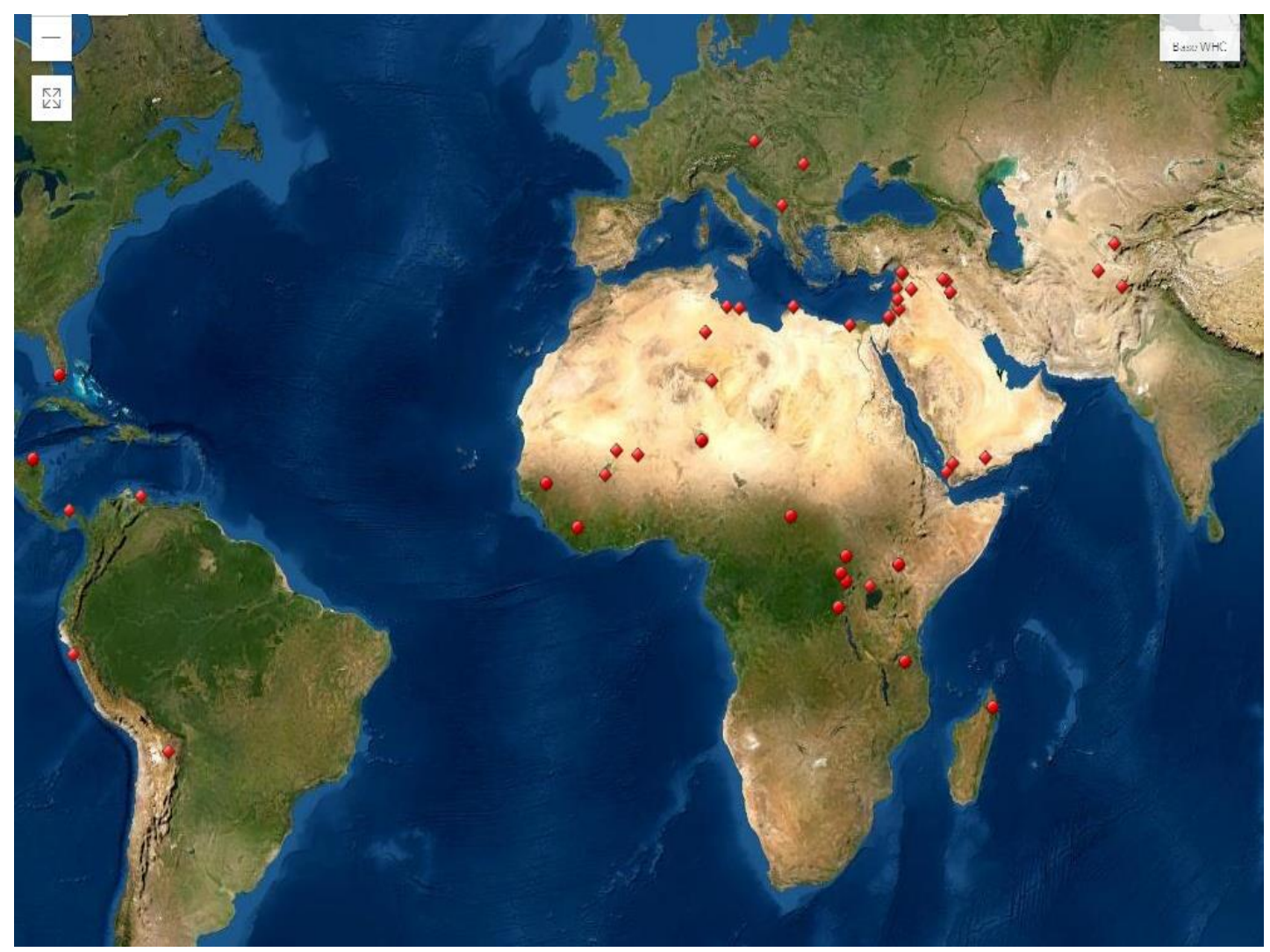

Извор: http://whc.unesco.org/en/danger/

\section{Успешни реставрациски приказни}

Стариот град Дубровник во Хрватска „Бисерот на Јадранот“, преполн со прекрасни готски, ренесансни и барокни згради, Во ноември и декември 1991 година, кога беше сериозно оштетен од артилериски оган, градот веднаш беше вклучен на листата на светско наследство во опасност. Со обезбедување на технички совети и финансиска помош од УНЕСКО, хрватската влада ги обнови фасадите на францисканските и доминиканските манастири, поправи покриви и повторно изгради палати. Како резултат на тоа, во декември 1998 година, се создадоа услови да се отстрани градот од Списокот на светско наследство во опасност.

Солниот рудник Виличка, во близина на Краков во Полска е впишан во 1978 година на Листата на светско наследство на УНЕСКО. Овој рудник активно работи од 13 век. Рудникот е познат по неговите галерии долги 300 километри кој содржи познати уметнички дела со олтари и статуи извајани во сол, а сите тие беа сериозно загрозени од влажноста поради воведувањето вештачка вентилација кон крајот на 19 век. Местото беше ставено на Листата на светско наследство во опасност во 1989 година. По деветгодишните заеднички напори на надлежните институции на Полска и меѓународната заедница, беше инсталиран ефикасен систем за одвлажнување. По успешното завршување на оваа активност, Комитетот за светско 
наслество, на седницата во декември 1998 година, донесе Одлука за отстранување на локалитетот од Списокот на светско наследство во опасност.

Анкор, Камбоџа како еден од најважните археолошки локалитети во Југоисточна Азија, поседува остатоци од различните престолнини на Кмерската империја, од 9 до 15 век. Нелегалните ископувања, грабежите на археолошките локалитети и нагазни мини беа главните проблеми на овој локалитет. Во 1993 година, УНЕСКО започна амбициозен план за заштита и развој на историскиот локалитет. Комитетот за светско наследство, откако констатира дека овие закани за локалитетот повеќе не постојат и дека бројните активности за конзервација и реставрација координирани од УНЕСКО беа успешни, го отстрани местото од Листата на светско наследство во опасност во 2004 година.

\section{Меѓуународни кампањи на УНЕСКО}

УНЕСКО од почетокот на 1960 година започна да води кампањи за превентивна заштита на светското наследство, кои во практиката се покажаа како мошне успешни. Во продолжение ќе наведеме неколку такви кампањи кои се покажаа како многу успешни.

Градот Венеиија, Италија. Најдолгата меѓународна кампања за заштита на светското природно и културно наследство во светот, е кампањата за заштита на градот Венеција која започна во далечната 1966 година, кога УНЕСКО одлучи да започне кампања за спасување на градот по катастрофалните поплави во 1965 година. Оваа кампања сеуште трае.

Археолошкиот локалитет Делфи во Гриија во времето на неговата номинација во 1987 година, било планирано изградба на фабрика за алуминиум во близина на локалитетот. За да се зашува универзалната вредност на локалитетот Делфи, УНЕСКО предложи Грчката влада да најде друга локација за изградба на фабриката, а Грчката влада го прифати предлогот, по што Делфи се најде на листата на светско наследство.

Националниот парк Ројал Читван во Непал е живеалиште на околу 400 носорози со еден рог, карактеристични за Јужна Азија. Владата на Непал изработи проект за пренасочување на реката Рапти, без да направи сеопфатна проценка на влијанието врз животната средина. Комитетот за светско наследство, во почетокот на 1990-ти, ги доведе во прашање наодите од проценката на влијанието врз животната средина на предложениот проект. Владата на Непал ја ревидираше проценката и утврди дека проектот за пренасочување на реката ќе ги загрози крајбрежните живеалишта на еднорогиот носорог во НП Ројал Читван. Така, проектот беше напуштен и ова место беше зачувано за идните генерации.

\section{Заклучок}

Врз основа на претходно наведеното можеме да заклучиме дека Листите на УНЕСКО имаат важна улога во заштитата на природното и културното наследство во светот. Тие се своевиден маркетинг на природното и културното наследство на државите на чија територија се наоѓa истото. Но, Листите се и еден вид опомена и предупредување да се чува природното наследство како благодат за идните генерации. Веб-страната на УНЕСКО е многу добро дизајнирана и претставува добра алатка за добивање на потребни информации за културното и природното наследство во сите држави во светот, меѓу кои и РМ. Сите Листи на УНЕСКО всушност се еден вид на меѓународни стандарди за превенција и заштита на светското наследство (природно и културно), кои државите членки треба да ги почитуваат. Исто така, Листите на УНЕСКО се добар туристички водич од кои можеме да црпеме релевантни информации за местоположбата на природното и културното наследство кои туристот ќе го поттикнат за туристички патувања и учество на некој настан со туристички вредности (карневал, фестивал и сл.). 
Листата на УНЕСКО за светско наследство во опасност ни дава прецизни информации за причините и природата на опасноста, со што на потенцијалниот посетител му обезбедува важни информации за состојбата во која се наоѓа одредено светско наследство. Исто така, Листите на УНЕСКО на светско наследство во опасност се важен меѓународен фактор за превентивната заштита на природното и културното наследство и мобилизациски фактор на националните власти да преземат соодветни мерки и активности за зачувување на светското наследство. Листата на светско наследство во опасност е дизајниран да ја информира меѓународната заедница за состојбите, кои ги загрозуваат самите карактеристики за кои имотот е запишан на листата на светско наследство и да поттикне корективни активности. Типичните закани што водат кон листата на опасности вклучуваат вооружен конфликт, природна катастрофа, непланиран урбан развој, ловокрадство и загадување. УНЕСКО од почетокот на 1960 година започна да води кампањи за превентивна заштита на светското наследство, која во практиката се покажаа како мошне успешна активност во заштитата на светското природно и културно наследство. Според Листата на УНЕСКО на светски наследства во опасност утврдено е дека 52 места (локалитети) се наоѓаат во опасност во 32 држави во светот. Според регионалната разместеност на светските наследства во опасност најмногу се наоѓаат во регионите каде има воени конфликти и природни катастрофи, како на пример во Арапските држави (21) и Африка (15). Со помош на УНЕСКО, национаните влади, меѓународни фондации и НВО голем број на локалитети кои се под заштита на УНЕСКО биле успешно реставрирани и обновени. Најдобар пример за тоа во нашето окружување е стариот дел на градот Дубровник, кој во 1991 година беше ставен на Листата во опасност, за да по неговата успешна реставрација во 1998 година беше симнат од таа Листа.

\section{Референци}

1) Мајхошев, Д. (2021), Услови и перспективи за развој на урбаниот туризам во Република Македонија, 2-ри Август, Штип;

2) Majhosev, Darko and Koteski Cane (2019), Unesco Lists for the Protection of Natural Cultural Heritage in the World and their impact on Tourism Development: Case of the Republic of North Republic of Macedonia. International Journal Knowledge, Vol. 34.5, pp. 1265-1271;

3) Majhosev, D (2019), UNESCO'S Role in the Protection of Natural and Cultural Heritage: Case study of the Ohrid Region, pp. 95-104, The $2^{\text {nd }}$ International Scientific Conference "Chalenges of Tourism and Business logistics in the $21{ }^{\text {st }}$ Century;

4) Соопштение на УНЕСКО на ден 28.07.2021 година

5) National Commissions for UNESCO, Annual Report, 2017, p. 132;

6) https://whc.unesco.org/en/158/

7) https://whc.unesco.org/en/sessions/44COM/

8)http://www.unesco.org/new/en/communication-and-information/memory-of-the world/register/full-list-of-registered-heritage/registered-heritage-page-8/, пристапено на ден 10.08.2021 година

9)http://www.unesco.org/new/en/communication-and-information/memory-of-the world/register/full-list-of-registered-heritage/registered-heritage-page-8/, отоврена на ден 10.08.2021 година

10) http://whc.unesco.org/en/list, пристапено на ден 26.07.2021 година;

11) http://whc.unesco.org/en/158/, пристапено на 26.07.2021;

12) https://whc.unesco.org/en/danger/, пристапено на ден 20.07.2019;

13) http://whc.unesco.org/en/nominations/, пристапено на 08.07.2019;

14) https://en.unesco.org/creative-cities/bitola, пристапено на ден 15.09.2019;

15)http://www.unesco.org/new/en/natural-sciences/environment/earth-sciences/unescoglobal geoparks/application-process/, пристапено на ден 27.07.2021;

16) https://ich.unesco.org/en/lists, пристапено на ден 15.08.2019;

17) https://en.unesco.org/biosphere/wnbr, пристапено на ден 15.08.2021; 